\title{
Intrascleral dissemination of infectious scleritis following pterygium excision
}

\begin{abstract}
Ching-Hsi Hsiao, James J Y Chen, Samuel C M Huang, Huey-Kang Ma, Phil Y F Chen,
\end{abstract} Ray J F Tsai ritis. To try to ascertain the relation of multiple scleral abscesses to infectious scleritis, we focused on these cases of infectious scleritis in association with multiple scleral abscesses following pterygium excision and took cultures from the scleral nodules to study the possible pathogenesis. We also discuss the clinical features and management of this potentially devastating condition.

\section{Patients and methods}

We reviewed the medical records of patients who developed multiple scleral nodules associated with infectious scleritis following pterygium excision and were treated at our hospital from 1988 to the end of 1995. That is, the patients presented with culture proved infectious scleritis at the bare sclera of pterygium excision and then multiple sclera nodules appeared. Twenty three patients met these clinical criteria. Five were excluded from analysis because of loss to follow up or incomplete documentation. Pterygium excision leaving bare sclera, without lamellar keratectomy, had been performed in all patients. The records regarding adjuncts to pterygium excision including $\beta$ irradiation, thiotepa, and mitomycin $\mathrm{C}$ were reviewed whenever possible, but only six such records were available.

\section{Results}

The results are presented in Table 1 . The average age of the patients at the time of admission was 67.5 (SD 9.0) years (range 40 to 79 years). There were six men and 12 women. The latency period between the time of pterygium excision and the onset of infectious scleritis was 8.9 (10.5) years (range 1 week to 32 years). Of the six patients for whom records regarding adjunctive therapy were available, three received topical mitomycin $\mathrm{C}$ or mitomycin $\mathrm{C}$ soaking, one was given topical thiotepa, and two received nothing. The mean follow up period was 6.4 (5.1) months (range 1 to 18 months).

The initial cultures taken from the base of the scleral ulcer revealed Pseudomonas aeruginosa in 12 cases, with Aspergillus and Mycobacterium fortuitum each accounting for one case. In four patients, there was mixed flora. Cultures from subsequent abscesses were obtained in 15 cases; the same isolates as the initial ones were identified in 12 cases, with no organisms cultured in three cases.

All 18 patients presented with scleral ulcers at the pterygium excision site, with one or more abscesses at other sites. Characteristically, the abscesses manifested as yellowish process or an immune response, they may complicate the management of infectious scle- 


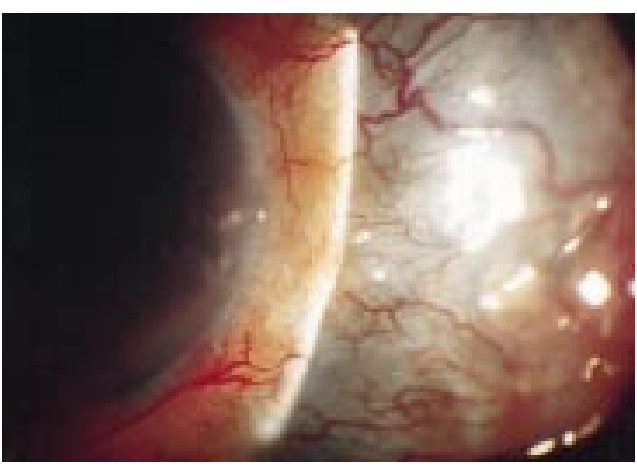

Figure 1 Case 1. Scleral thinning from original ulcer through subsequent abscess extended in an arc shape.

nodules under the intact conjunctival epithelium and were scattered either superiorly or inferiorly along an arc 3-4 $\mathrm{mm}$ from the limbus. In some cases, the abscess appeared $180^{\circ}$ away from the initial ulcer. A black arc-shaped band extending from the initial ulcer site through subsequent abscesses, a result of scleral thinning, was identified in almost all patients (Fig 1) after resolution of the infection. In one patient (case 6), concentric ectasia of the globe occurred when a ring of multiple sclera abscesses resolved leading to scleral thinning. There were calcific plaques at the base of ulcer beds in 10 patients. At initial presentation, 13 patients had anterior uveitis. In three of the involved eyes, the scleral ulcer later extended to the adjacent cornea. Three patients initially manifested limited extraocular muscle movement that mimicked a pseudotumour or orbital cellulitis.

There were three major associated complications including recurrence of infectious scleritis, serous retinal or choroidal detachment, and complicated cataract. Four patients had recurrence of initial scleritis in an area previously not involved. In other words, another abscess was identified only after the original scleral ulcer had been healed for a period of time. Four patients developed serous retinal detachment, three developed choroidal detachment, and two had choroidal and retinal detachment simultaneously. A complicated cataract was noted in five eyes.

All patients were given fortified antibiotic eyedrops when the infection developed. Initially, patients were treated with gentamicin
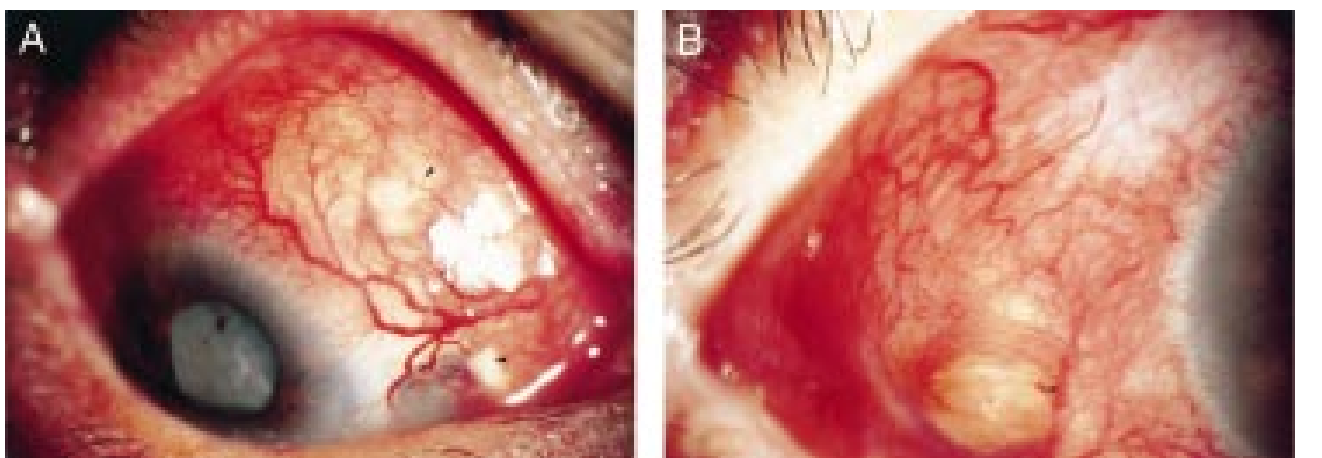

Figure 2 Case 5. (A) Multiple scleral abscesses (arrowheads) developed 3 weeks after excision of a nasal pterygium with mitomycin $C$ used as adjunct. (B) $A$ new abscess (arrowhead) at the temporal sclera, $180^{\circ}$ from the initially involved area, was noted 1 month after discharge. and cefazolin sodium for Gram positive coverage. Gentamicin was changed to amikacin in six patients, because sensitivity testing indicated the Pseudomonas species were more sensitive to amikacin. The patient with scleritis caused by Aspergillus was not treated with amphotericin B eyedrops until 17 days later when the culture results were reported. Three patients were treated with eyedrops alone and 15 patients received topical plus intravenous antibiotics. Three patients receiving gentamicin developed elevated creatinin levels, which returned to normal limits following discontinuation of the drug.

Fourteen infected eyes received operative treatment in conjunction with antimicrobial therapy. Cryotherapy was performed on two of these eyes. A conjunctival flap was performed for one of these patient, in addition to cryotherapy. Early debridement of scleral ulcers was undertaken for six of the eyes. Conjunctival flaps were used to cover the ulcers in six patients after the infection was controlled. Four of these patients required eventual enucleation.

The final visual acuities are presented in Table 1. Four patients underwent enucleation, 11 retained useful vision (better than or equal to $2 / 200$ ), and three had poor vision (worse than $2 / 200$ to light perception).

\section{Case reports}

CASE 5

An otherwise healthy 71 year old woman underwent excision of a nasal pterygium of the right eye in May 1992. A cellulose sponge soaked with mitomycin C $(0.2 \mathrm{mg} / \mathrm{ml})$ was applied to the bare sclera for about 5 minutes. Three weeks after surgery she was referred to our hospital because of progressive decreased vision and pain. Visual acuity was right eye $20 / 200$ and left eye 20/40. Slit lamp examination of the right eye demonstrated scleral necrosis and an abscess near the site of the pterygium excision, with no anterior chamber inflammation. The patient was treated with topical fortified cefazolin sodium and gentamicin. Cultures of scleral surface scrapings were positive for $P$ aeruginosa, $P$ lactobacilli, $N$ subflava, and $N$ stomatococci of light growths. Multiple subconjunctival nodular excrescences (Fig 2A) with fibrinoid aqueous reaction 
Table 1 Infectious scleritis with multiple scleral abscesses *

\begin{tabular}{|c|c|c|c|c|c|c|c|c|}
\hline \multirow{2}{*}{$\begin{array}{l}\text { Case/ age } \\
(y) / \text { sex/eye }\end{array}$} & \multirow{2}{*}{$\begin{array}{l}\text { Adjuncts to } \\
\text { pterygium } \\
\text { excision }\end{array}$} & \multirow{2}{*}{$\begin{array}{l}\text { Latency } \\
\text { period }\end{array}$} & \multirow[b]{2}{*}{ Organismst } & \multirow[b]{2}{*}{ Cinical features } & \multicolumn{2}{|l|}{ Treatment } & \multirow[b]{2}{*}{ Final VA } & \multirow[b]{2}{*}{ Complication(s) } \\
\hline & & & & & Medical & Surgical & & \\
\hline $1 / 68 / \mathrm{F} / \mathrm{R}$ & NA & $11 \mathrm{y}$ & $\begin{array}{l}1 \text { Enterobacterium } \\
\text { cloacae; } \\
\text { Pseudomonas } \\
\text { aeruginosa } \\
2 \text { P aeruginosa }\end{array}$ & $\begin{array}{l}\text { Scleral abscesses; calcific } \\
\text { plaque; ant uveitis; corneal } \\
\text { infiltrate }\end{array}$ & $\begin{array}{l}\text { Topical and } \\
\text { systemic cefazolin } \\
\text { sodium and } \\
\text { amikacin }\end{array}$ & $\begin{array}{l}\text { Debridement; } \\
\text { enucleation }\end{array}$ & - & None \\
\hline $2 / 72 / \mathrm{M} / \mathrm{R}$ & NA & $3 \mathrm{~m}$ & $\begin{array}{l}1 \text { P aeruginosa } \\
2 \text { P aeruginosa }\end{array}$ & $\begin{array}{l}\text { Scleral abscesses; ant } \\
\text { uveitis; corneal infiltrate; } \\
\text { limited EOM }\end{array}$ & $\begin{array}{l}\text { Topical cefazolin } \\
\text { sodium and } \\
\text { amikacin }\end{array}$ & Enucleation & - & None \\
\hline $3 / 73 / \mathrm{F} / \mathrm{R}$ & NA & $10 \mathrm{y}$ & 1 Aspergillus & $\begin{array}{l}\text { One scleral abscess in the } \\
\text { first episode; calcific } \\
\text { plaque; ant uveitis }\end{array}$ & $\begin{array}{l}\text { Topical cefazolin } \\
\text { sodium and } \\
\text { gentamicin, then } \\
\text { amphotericin } B \mathbb{S}\end{array}$ & $\begin{array}{l}\text { Debridement; } \\
\text { enucleation }\end{array}$ & - & Recurrence \\
\hline $4 / 40 / \mathrm{F} / \mathrm{R}$ & NA & $8 \mathrm{y}$ & $\begin{array}{l}1 \text { P aeruginosa } \\
2 \text { No growth }\end{array}$ & $\begin{array}{l}\text { Scleral abscesses; calcific } \\
\text { plaque; ant uveitis; limited } \\
\text { EOM }\end{array}$ & $\begin{array}{l}\text { Topical cefazolin } \\
\text { sodium and } \\
\text { gentamicin and } \\
\text { systemic gentamicin }\end{array}$ & None & $20 / 30$ & None \\
\hline $5 / 71 / \mathrm{F} / \mathrm{R}$ & $\begin{array}{l}\text { Mitomycin } \\
\text { C soaking }\end{array}$ & $21 \mathrm{~d}$ & $\begin{array}{l}1 \text { P aeruginosa; } \\
\text { Lactobacillus; } N \\
\text { subflava; } \\
\text { Stomatococcus } \\
2 P \text { aeruginosa }\end{array}$ & $\begin{array}{l}\text { Scleral abscesses; calcific } \\
\text { plaque }\end{array}$ & $\begin{array}{l}\text { Topical cefazolin } \\
\text { sodium and } \\
\text { gentamicin and } \\
\text { systemic gentamicin }\end{array}$ & Cryotherapy & $20 / 200 \ddagger$ & $\begin{array}{l}\text { Recurrence; } \\
\text { complicated } \\
\text { cataract }\end{array}$ \\
\hline $6 / 63 / \mathrm{F} / \mathrm{R}$ & NA & $12 \mathrm{y}$ & $\begin{array}{l}1 \text { P aeruginosa } \\
2 \text { No growth }\end{array}$ & $\begin{array}{l}\text { One scleral abscess in the } \\
\text { first episode; ant uveitis; } \\
\text { limited EOM }\end{array}$ & $\begin{array}{l}\text { Topical and sytemic } \\
\text { gentamicin }\end{array}$ & Conjunctival flap & $20 / 200 \ddagger$ & $\begin{array}{l}\text { Recurrence; } \\
\text { complicated } \\
\text { cataract; inferior } \\
\text { retinal } \\
\text { detachment }\end{array}$ \\
\hline $7 / 65 / \mathrm{M} / \mathrm{R}$ & None & $8 \mathrm{y}$ & $\begin{array}{l}1 \text { Bacillus; } \\
\text { Staphylococcus } \\
\text { epidermidis; } \\
\text { Escherichia cloacae }\end{array}$ & $\begin{array}{l}\text { Scleral abscesses; ant } \\
\text { uveitis }\end{array}$ & $\begin{array}{l}\text { Topical and } \\
\text { systemic gentamicin }\end{array}$ & None & $20 / 200$ & $\begin{array}{l}\text { Total retinal } \\
\text { detachment; } \\
\text { complicated } \\
\text { cataract }\end{array}$ \\
\hline $8 / 74 / \mathrm{M} / \mathrm{R}$ & NA & $32 \mathrm{y}$ & $\begin{array}{l}1 \text { P aeruginosa } \\
2 \text { P aeruginosa }\end{array}$ & $\begin{array}{l}\text { Scleral abscesses; calcific } \\
\text { plaque }\end{array}$ & $\begin{array}{l}\text { Topical and } \\
\text { systemic gentamicin }\end{array}$ & Conjunctival flap & $20 / 400$ & $\begin{array}{l}\text { Inferior retinal } \\
\text { detachment; } \\
\text { complicated } \\
\text { cataract }\end{array}$ \\
\hline $9 / 78 / \mathrm{F} / \mathrm{R}$ & $\begin{array}{l}\text { Topical } \\
\text { thiotepa }\end{array}$ & $7 \mathrm{~d}$ & $\begin{array}{l}1 \text { P aeruginosa } \\
2 \text { No growth } \\
3 \text { P aeruginosa }\end{array}$ & $\begin{array}{l}\text { Scleral abscesses; ant } \\
\text { uveitis }\end{array}$ & $\begin{array}{l}\text { Topical cefazolin } \\
\text { sodium and } \\
\text { amikacin; systemic } \\
\text { ticarcillin and } \\
\text { amikacin }\end{array}$ & Debridement & $20 / 50$ & None \\
\hline $10 / 61 / \mathrm{F} / \mathrm{L}$ & NA & $1 \mathrm{~m}$ & $\begin{array}{l}1 S \text { epidermis; } P \\
\text { aeruginosa } \\
2 P \text { aeruginosa }\end{array}$ & $\begin{array}{l}\text { Scleral abscesses; ant } \\
\text { uveitis }\end{array}$ & $\begin{array}{l}\text { Topical and } \\
\text { systemic cefazolin } \\
\text { sodium and } \\
\text { gentamicin }\end{array}$ & Debridement & HM & None \\
\hline $11 / 61 / \mathrm{M} / \mathrm{L}$ & $\begin{array}{l}\text { Mitomycin } \\
\text { C soaking }\end{array}$ & $21 \mathrm{~d}$ & $\begin{array}{l}1 \text { P aeruginosa } \\
2 \text { P aeruginosa }\end{array}$ & Scleral abscesses & $\begin{array}{l}\text { Topical cefazolin } \\
\text { sodium and } \\
\text { gentamicin systemic } \\
\text { gentamicin and } \\
\text { amikacin }\end{array}$ & $\begin{array}{l}\text { Cryotherapy; } \\
\text { conjunctival flap }\end{array}$ & $20 / 50$ & None \\
\hline $12 / 79 / \mathrm{F} / \mathrm{R}$ & NA & $32 \mathrm{y}$ & 1 P aeruginosa & $\begin{array}{l}\text { Scleral abscesses; calcific } \\
\text { plaque }\end{array}$ & $\begin{array}{l}\text { Topical cefazolin } \\
\text { sodium and } \\
\text { gentamicin; systemic } \\
\text { gentamicin }\end{array}$ & Conjunctival flap & $\mathrm{CF}$ & $\begin{array}{l}\text { Inferior retinal } \\
\text { detachment }\end{array}$ \\
\hline $13 / 62 / \mathrm{F} / \mathrm{L}$ & $\begin{array}{l}\text { Topical } \\
\text { mitomycin } \\
\text { C }\end{array}$ & $3.5 \mathrm{y}$ & $\begin{array}{l}1 \text { P aeruginosa } \\
2 \text { P aeruginosa } \\
3 \text { P aeruginosa }\end{array}$ & $\begin{array}{l}\text { Scleral abscesses; calcific } \\
\text { plaque; ant uveitis; corneal } \\
\text { infiltrate and perforation }\end{array}$ & $\begin{array}{l}\text { Topical cefazolin } \\
\text { sodium and } \\
\text { gentamicin; systemic } \\
\text { gentamicin }\end{array}$ & $\begin{array}{l}\text { Glue; conjunctival } \\
\text { flap; enucleation }\end{array}$ & - & $\begin{array}{l}\text { Choroidal and } \\
\text { total retinal } \\
\text { detachment; } \\
\text { complicated } \\
\text { cataract }\end{array}$ \\
\hline $14 / 70 / \mathrm{M} / \mathrm{R}$ & NA & $1.5 \mathrm{y}$ & $\begin{array}{l}1 \text { P aeruginosa } \\
2 \text { P aeruginosa }\end{array}$ & $\begin{array}{l}\text { Scleral abscesses; calcific } \\
\text { plaque; ant uveitis }\end{array}$ & $\begin{array}{l}\text { Topical cefazolin } \\
\text { sodium and } \\
\text { amikacin; systemic } \\
\text { amikacin }\end{array}$ & Debridement & LP & $\begin{array}{l}\text { Choroidal } \\
\text { detachment }\end{array}$ \\
\hline $15 / 63 / \mathrm{F} / \mathrm{R}$ & NA & $3 y$ & $\begin{array}{l}1 M \text { fortuitum } \\
2 \text { No growth } \\
3 \text { No growth }\end{array}$ & Scleral abscesses & $\begin{array}{l}\text { Topical cefazolin } \\
\text { sodium and } \\
\text { amikacin; systemic } \\
\text { amikacin }\end{array}$ & None & $20 / 100$ & Recurrence \\
\hline $16 / 72 / \mathrm{F} / \mathrm{R}$ & None & $3 y$ & $\begin{array}{l}1 \text { P aeruginosa } \\
2 P \text { aeruginosa }\end{array}$ & $\begin{array}{l}\text { Scleral abscesses; calcific } \\
\text { plaque; ant uveitis }\end{array}$ & $\begin{array}{l}\text { Topical cefazolin } \\
\text { sodium and } \\
\text { amikacin; systemic } \\
\text { amikacin }\end{array}$ & None & $20 / 200$ & $\begin{array}{l}\text { Choroidal } \\
\text { detachment }\end{array}$ \\
\hline $17 / 76 / \mathrm{F} / \mathrm{L}$ & NA & $25 \mathrm{y}$ & $\begin{array}{l}1 \text { P aeruginosa } \\
2 \text { P aeruginosa }\end{array}$ & $\begin{array}{l}\text { Scleral abscesses; calcific } \\
\text { plaque; ant uveitis }\end{array}$ & $\begin{array}{l}\text { Topical cefazolin } \\
\text { sodium and } \\
\text { amikacin; systemic } \\
\text { amikacin }\end{array}$ & $\begin{array}{l}\text { Debridement; } \\
\text { conjunctival flap }\end{array}$ & $20 / 200$ & $\begin{array}{l}\text { Choroidal } \\
\text { detachment }\end{array}$ \\
\hline $18 / 68 / \mathrm{F} / \mathrm{L}$ & NA & $10 \mathrm{y}$ & $\begin{array}{l}1 \text { P aeruginosa } \\
2 \text { P aeruginosa } \\
3 \text { P aeruginosa }\end{array}$ & $\begin{array}{l}\text { Scleral abscesses; ant } \\
\text { uveitis }\end{array}$ & $\begin{array}{l}\text { Topical cefazolin } \\
\text { sodium and } \\
\text { gentamicin; systemic } \\
\text { gentamicin }\end{array}$ & Conjunctival flap & $20 / 100$ & $\begin{array}{l}\text { Choroidal and } \\
\text { retinal } \\
\text { detachments }\end{array}$ \\
\hline
\end{tabular}

${ }^{\star}$ Modifed from Moriarty et al. ${ }^{11}$

$\dagger 1=$ Result of first culture from initial scleral ulcer; $2,3=$ second and third culture result of subsequent abscesses.

$\ddagger$ VA after extracapsular cataract extraction and intraocular lens implantation; $₫$ after the return of the culture reports.

$\mathrm{NA}=$ not available; $\mathrm{y}=$ year; $\mathrm{m}=$ month; $\mathrm{d}=\mathrm{day}$; ant=anterior; $\mathrm{EOM}=$ extraocular movements; $\mathrm{VA}=$ visual acuity; $\mathrm{HM}=$ hand movement; $\mathrm{CF}=$ counting fingers. 

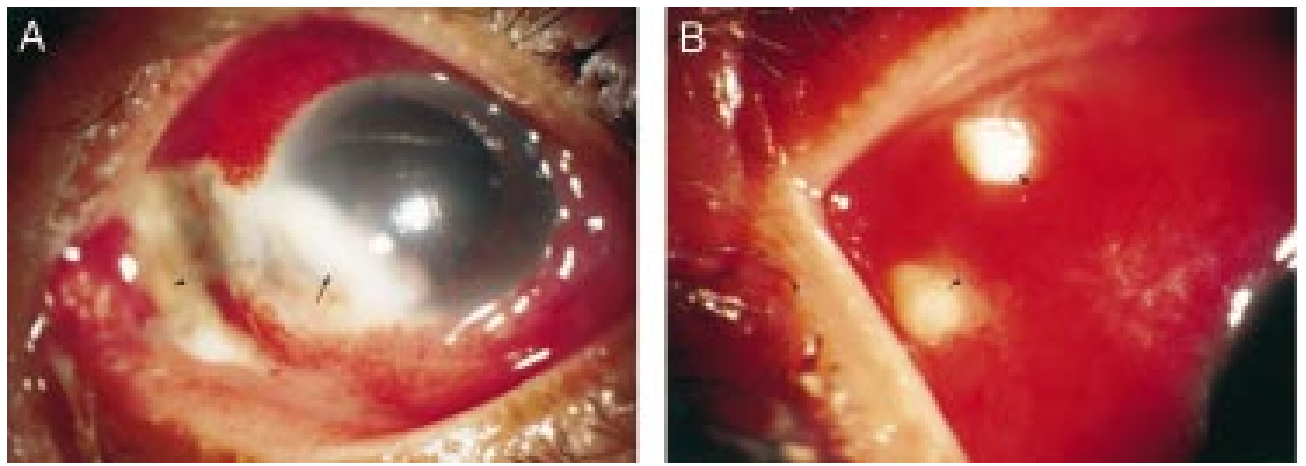

Figure 3 Case 13. (A) At presentation there was a calcific plaque over the scleral ulcer bed (arrowhead). The ulcer progressed and became contiguous with a corneal infiltrate (arrow). (B) Multiple new nodules (arrowheads) from which $P$ aeruginosa was cultured, appeared on the 22nd day of hospitalisation.

developed in the following days, and cultures from these abscesses grew $P$ aeruginosa. Intravenous gentamicin ( $60 \mathrm{mg} / 8$ hours) was begun on the fifth day of hospitalisation. Symptoms and the initial ulcer improved over the next 8 weeks, and dosage was tapered. Ten weeks after admission, cryotherapy was performed on the temporal sclera, where the abscess had increased in size. The condition then came under control. The patient was discharged after 12 weeks of hospitalisation, on a regimen of topical gentamicin and corticosteroid application four times a day. Her visual acuity in the right eye was hand movements at 3 feet. The poor vision may have been a result of total opacity of the lens.

One month later, the patient developed severe eye pain and noted a further deterioration in vision. The visual acuity of her right eye was hand movements at 4 inches. There was thinning of the sclera superonasally and inferonasally. A new abscess was noted in the region on the temporal sclera (Fig 2B) and $P$ aeruginosa was isolated from subsequent cultures. She was hospitalised again and given topical fortified gentamicin and intravenous amikacin (350 mg/12 hours). Her scleral abscess healed after 6 weeks, but her visual acuity remained only light perception. She

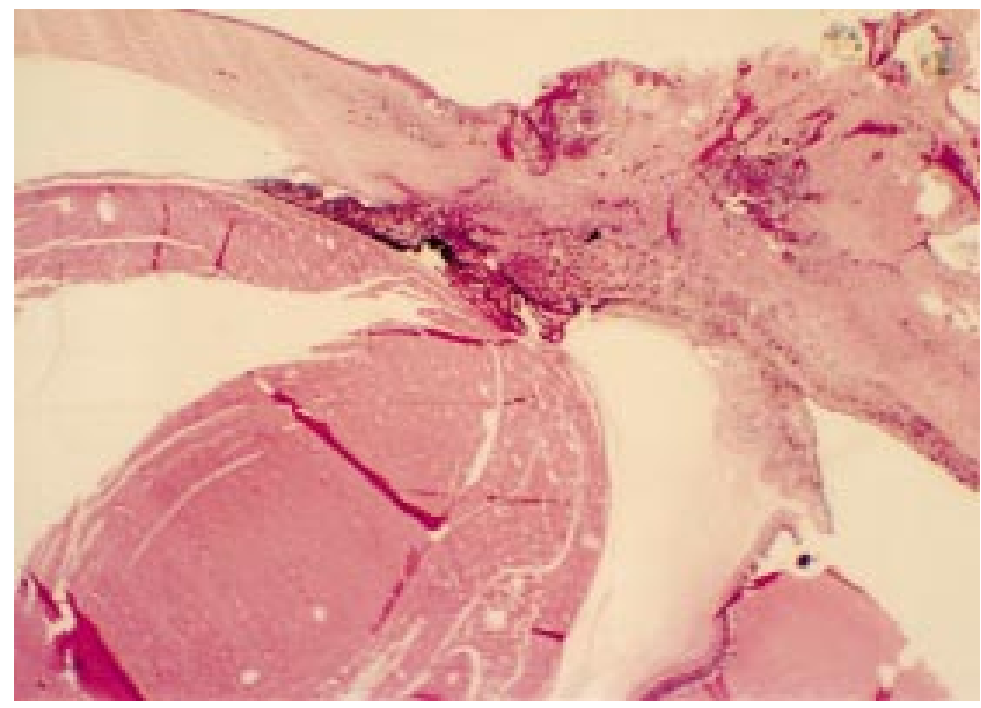

Figure 4 Case 13. Chronic inflammatory cells infiltrated the supraciliary space (arrowhead) (haematoxylin and eosin, $\times 5$ ). underwent a successful extracapsular cataract extraction with intraocular lens implantation 18 months later and achieved a visual acuity of $20 / 200$ at 3 month follow up.

\section{CASE 7}

A 65 year old man who underwent removal of a left nasal pterygium without any adjunct therapy 8 years earlier, developed a red and painful left eye 1 month before this admission. Left eye visual acuity was only light perception. Slit lamp examination showed a necrotic scleral ulcer over the pterygium excision site and severe oedema and congestion of the temporal conjunctiva. The anterior chamber was deep, with +2 cells and flare. There was a total serous retinal detachment. Two days after admission, two new scleral nodules developed in areas not adjacent to the original scleral ulcer. Therapy was initiated with hourly fortified topical cefazolin sodium and amikacin, as well as intravenous gentamicin (60 $\mathrm{mg} / 8$ hours). Since culture results from scleral scrapings grew a mixed flora of Bacillus species, Staphylococcus epidermis, and Enterobacter cloacae, the regimen was continued for 2 weeks and the ocular condition improved progressively. Oral prednisone $(20 \mathrm{mg} /$ day $)$ was added to the patient's regimen on the 15th day of hospitalisation and the serous detachment began to diminish gradually. The patient was discharged on the 24th hospital day on fortified topical amikacin and oral prednisone $10 \mathrm{mg}$ per day. The serous detachment resolved completely after 3 months. Six months later the patient's best corrected vision was 20/200, with scleral thinning and a complicated cataract.

CASE 13

A 62 year old woman had a left nasal pterygium excised in 1991, leaving bare sclera, and received adjunctive topical mitomycin C $(0.2 \mathrm{mg} / \mathrm{ml})$ for the next 2 weeks. In 1994, she developed a red painful left eye. At presentation, her visual acuity was counting fingers at 4 inches in the left eye. Marked anterior chamber flare and cellular reaction were present with a definite necrotic scleral ulcer over the pterygium excision site. A calcific plaque covered the ulcer bed (Fig 3A). Ultrasound demonstrated a choroidal detachment and an inferior retinal detachment. The patient was admitted 


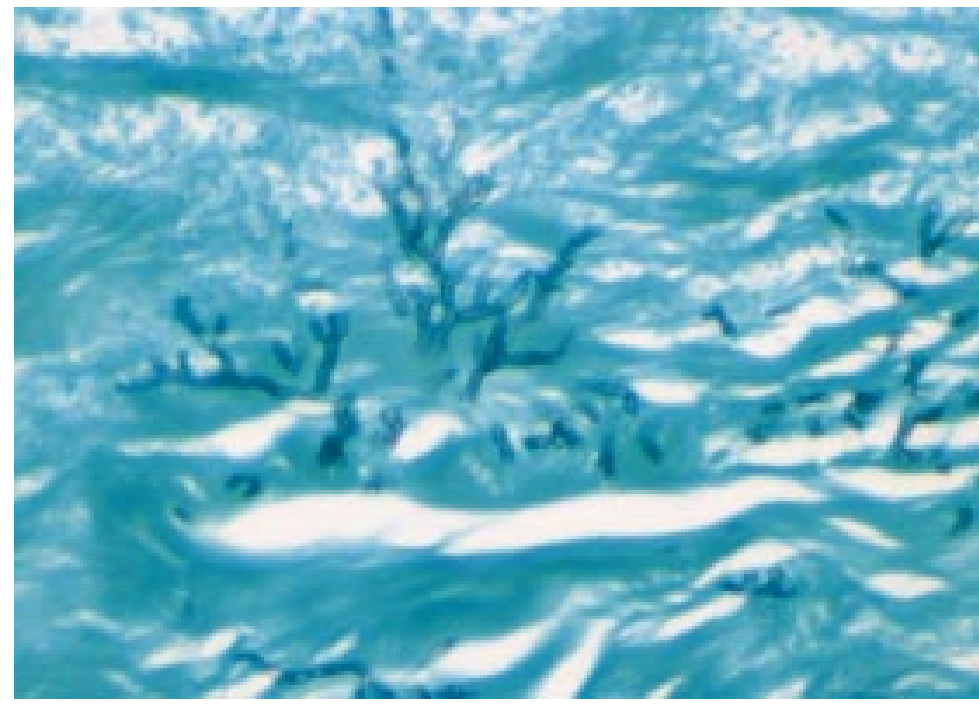

Figure 5 Fungal elements were present in the enucleated specimen from case 3 (Gomori's methenamine silver, $\times 230$ ).

and started on topical antibiotics. After 2 days, the scleral ulcer progressed and was contiguous with a corneal infiltrate (Fig 3A). A $3 \mathrm{~mm}$ hypopyon was also present. Culture of the necrotic sclera revealed a heavy growth of $P$ aeruginosa. The patient was given intravenous gentamicin ( $60 \mathrm{mg} / 8$ hours). On the 19 th hospital day, a small perforation adjacent to the nasal limbus was noted and tissue glue was applied to the site. The patient was treated with the same regimen. Multiple discrete, yellowish scleral nodules (Fig 3B), from which $P$ aeruginosa was cultured, appeared one by one within the first month. The abscesses slowly resolved, with the ocular condition stabilising gradually. A conjunctival flap for reconstruction was performed 52 days after admission. The patient was discharged on topical fortified antibiotics after 2 months of hospitalisation. Her visual acuity was light perception only with no evidence of inflammation and B-scan ultrasonography disclosed a funnel-shaped retinal detachment. The left eye gradually became more painful and phthisical. The pain was not relieved by narcotics, so she opted for an enucleation 3 weeks after discharge.

\section{Pathological findings}

The left globe measured $22 \times 22 \times 20 \mathrm{~mm}$; it showed a healed scleral ulcer. Microscopic examination disclosed foci of intense chronic inflammation of the cornea and sclera. The space between the sclera and the epithelium of the pars plana was greatly thickened by chronic inflammatory cells (Fig 4) including lymphocytes and plasma cells. There was a total exudative retinal detachment.

\section{Discussion}

Pterygium excision is a minor surgical procedure, but recurrence of the pterygium is frequent after simple excision alone. Adjunct therapy such as $\beta$ irradiation, thiotepa, and mitomycin have been used to decrease the recurrence rate. Infectious scleritis after pterygium excision, however, has been described in patients treated with postoperative $\beta$ irradiation $^{1-5}$ 7-10 and topical thiotepa. ${ }^{3}$ To the best of our knowledge, ours is the first report in which mitomycin use has been associated with infectious scleritis after pterygium excision. Because our hospital is a tertiary care centre, records of adjunct therapy were not available for 12 of the patients. However, because $\beta$ irradiation was not commonly used in Taiwan, it is unlikely that these patients received such therapy. Two patients without adjuncts also developed infectious scleritis in this study. It would appear that some common pathway in different procedures contributed to the scleral infection. It is conceivable that factors including faulty surgical technique, particularly cautery $^{18}$ and the use of mitomycin C, thiotepa, or $\beta$ irradiation destroy conjunctival and episcleral tissue and vessels; leaving the excised pterygium area with no protective tissue and no blood supply, and therefore little ability to resist infection. In addition, adjunctive therapy with $\beta$ irradiation and cytotoxic drugs would kill the few cells that are in the system, leaving a tissue totally unprotected and open to infection.

Multiple scleral abscesses associated with corneal ulcer, ${ }^{1112}$ endophthalmitis, ${ }^{13}{ }^{14}$ and infectious scleritis ${ }^{6915}$ have been documented, but only one case had received prior pterygium excision. ${ }^{6}$ In theory, any infectious agent may cause inflammatory microangiopathy in the sclera by inducing an immune mediated response in the vessel wall. ${ }^{16}$ Therefore, multiple scleral nodules in infectious scleritis can be hypothesised to result either from immune mediated vasculitis or from direct scleral invasion by organisms from the scleral ulcer at the site of pterygium excision. In this series, cultures taken from two different scleral nodules at two separate times in the same patient grew the same organism in 12 cases. A negative culture from a subsequent abscess was noted in three cases, but these abscesses resolved with antibiotics alone. This would suggest that the abscess formation represented an intrascleral dissemination of the infectious process, not an immune mediated phenomenon. In addition, scleral thinning between the original ulcer and abscess suggests the track of dissemination. On the other hand, some patients with non-infectious necrotising scleritis after ocular surgery share clinical pictures similar to those of our cases. ${ }^{17}$ However, surgically induced necrotising scleritis develops predominantly in patients with underlying systemic autoimmune vasculitic disease. ${ }^{17}$ In addition, cultures from the lesion site can lend further evidence to differentiate infectious from inflammatory process.

Infectious scleritis is vision threatening. Twenty two per cent of our patients (four of 18) underwent enucleation; three of them had infectious scleritis with corneal involvement and the other had Aspergillus infection. Furthermore, three patient (cases 1,2,3) who later required enucleation because of uncontrollable infection were treated with only topical antimicrobials. Reynolds and Alfonso ${ }^{10}$ reported that nine of their 17 cases of bacterial keratoscleritis required enucleation or evisceration, but 
none of the eight cases of bacterial scleritis did. This suggests that isolated infectious scleritis has a better prognosis than keratoscleritis. Possible factors contributing to poor prognosis with infectious scleritis following pterygium excision associated with multiple scleral abscesses may include corneal involvement, inappropriate antimicrobial therapy, and fungal infections. The sequelae of inflammation, such as uveitis, complicated cataract, choroidal detachment, and exudative retinal detachments may be, at least partially, responsible for the poor final vision observed in our series. Few cases of exudative retinal detachments and choroidal detachments have been reported on infectious scleritis following pterygium excision. ${ }^{3-5} 79$ The high percentage of choroidal and/or retinal detachments (nine of 18) in this survey is probably due to the severity of the infectious and inflammatory process.

Infectious scleritis is difficult to manage because of poor penetration of antimicrobials into the tightly bound collagen fibres of the scleral layer, which allows organisms to remain in the intrascleral lamellae for a long time. In 1987, Alfonso et $a l^{18}$ found persistence of Pseudomonas organisms in the sclera, despite intensive antibiotic therapy. In 1993, Moriarty et $a l^{4}$ reported fungal hyphae were still present in enucleated specimens from two patients in spite of systemic antifungal therapy for 3 and 6 months, respectively. We noted similar findings in case 3 (Fig 5). Thus, aggressive and prolonged topical and systemic antibiotics must be instituted, particularly in patients who are believed to have intrascleral dissemination of infectious scleritis. Reynolds and Alfonso ${ }^{10}$ suggested surgical management such as cryotherapy, lamellar or penetrating corneoscleral graft should be considered if a patient with infectious corneoscleritis or scleritis does not improve within the first few days of antibiotic treatment. Grafts performed before adequate systemic therapy, however, appear to have a high risk of necrosis and sloughing, both in our experience and others. ${ }^{4}$ It would appear prudent to delay grafts for reconstruction until the eye is clearly settled following prolonged antimicrobial treatment. Although corticosteroids may act as modulators of inflammatory response associated with infection, ${ }^{10} 1618$ they may lead to recurrence. Most authors recommend corticosteroids be used only after several days of intensive, appropriate antibiotic therapy. ${ }^{4} 10161819$ However, prevention is much more important than treatment. We should avoid inappropriate procedures, including overuse of cautery and adjunctive therapy, in pterygium excision. If the bare scleral area is ischaemic at follow up visits, covering the area with a conjunctiva autograft or Tenon's capsule might help to prevent further infection.

This is a retrospective report, and the implications are limited because of the incompleteness of clinical records. Further prospective studies are required to focus on which predisposing factors increase the likelihood of disseminated infectious scleritis, and the appropriate and standard treatment of such patients.

We report 18 cases of infectious scleritis associated with multiple scleral abscesses after pterygium excision. Since subsequent abscess cultures indicated the organism was the same as the initial one in many cases, it would appear that the formation of multiple abscesses represents an intrascleral dissemination of the infectious process. Early diagnosis and appropriate antimicrobial therapy are essential to halt the progression of these severe scleral infections. On the other hand, we believe it is very important to perform pterygium excision with appropriate surgical procedures and adjunctive therapy to prevent scleral necrosis from resulting in further severe infections.

1 Tarr $\mathrm{KH}$, Constable IJ. Late complications of pterygium treatment. Br F Ophthalmal 1980;64:496-505.

2 Tarr KH, Constable IJ. Pseudomonas endophthalmitis associated with scleral necrosis. Br F Ophthalmol 1980;64: 676-9.

3 Farrell PLR, Smith RE. Bacterial corneoscleritis complicating pterygium excision. Am $\mathcal{F}$ Ophthalmol 1989;107:515-7.

4 Moriarty AP, Crawfold GJ, McAllister IL, Constable IJ. Moriarty AP, Crawfold GJ, McAllister IL, Constable IJ.
Severe corneoscleral infection. Arch Ophthalmol 1993;111: Severe corn.

5 Moriarty AP, Crawfold GJ, McAllister IL, Constable IJ. Fungal corneoscleritis complicating beta irradiation- induced scleral necrosis following pterygium excision. Eye 1993;7:525-8

6 Lin CP, Wu YH, Chen MT, Huang WL. Repair of a giant scleral ulcer with a scleral graft and tissue glue (letter). $A m$ f Ophthalmol 1991;111:251.

7 Margo C E, Polack FM, Mood CI. Aspergillus panophthalmitis complicating treatment of pterygium. Cornea 1988;7:285-9.

8 Mackenzie FD, Hirst LW, Kynaston B, Bain C. Recurrence rate and complications after beta irradiation for pterygia. Ophthalmology 1991;98:1776-81.

9 Altman AJ, Cohen EJ, Berger ST, Mondino BJ. Scleritis and Streptococcus pneumoniae. Cornea 1991;10:341-5.

10 Reynolds MG, Alfonso E. Treatment of infectious scleritis and keratoscleritis. Am $\mathcal{F}$ Ophthalmol 1991;112:543-7.

11 Dougherty PJ, NBinder PS, Mondino BJ, Glasgon BJ. Acanthamoeba sclerokeratitis. Am F Ophthalmol 1994;117: 475-9.

12 Harbin T. Recurrence of a corneal pseudomonas infection. Am 7 Ophthalmol 1964;58:670.

13 Berler DK, Alper MG. Scleral abscesses and ectasia caused by Pseudomonas aeruginosa. Ann Ophthalmol 1982;14: $665-7$.

14 Ram J, Sharma A, Gupta A. Multiple scleral abscesses with recurrent bacterial endophthalmitis eight months following cataract surgery. Acta Ophthalmol 1990;68:615-6.

15 Carlson AN, Foulks GN, Perfect JR, Kim JH. Fungal scleritis after cataract surgery. Cornea 1991;10:341-5.

16 Foster CS, Maza Maite Sainz de la. The sclera: infectious scleritis. New York: Springer-Verlag, 1994:242-77.

17 Maza Maite Sainz de la, Foster CS. Necrotizing scleritis after ocular surgery: a clinicopathologic study. Ophthalmology 1991;98:1720-6.

18 Alfonso E, Kenyon KR, Ormerod LD, et al. Pseudomonas corneoscleritis. Am f Ophthalmol 1987;103:90-8.

19 Raber IM, Laibson PR, Kurz GH, Nernardino VB. Pseudomonas corneoscleral ulcers. Am f Ophthalmol 1981; 92:353-62. 